\author{
저에너지 사료로 비육된 돼지에서 도살체중과 성장성적 및 육질과의 관계

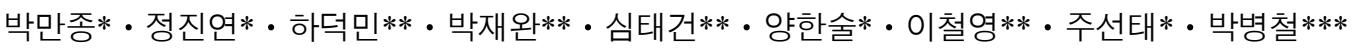 \\ 경상대학교 동물자원과학부*, 진주산업대학교 동물생명산업센터**, 씨제이제일제당주식회사***
}

\title{
Relationships of the Slaughter Weight to Growth Performance and Meat Quality Traits in Finishing Pigs Fed A Low-energy Diet
}

\author{
Man Jong Park*, Jin Yeun Jeong*, Duck Min Ha**, Jae Wan Park**, Tae Geon Sim**, Han Sul Yang*, \\ Chul Young Lee**, Seon Tea Joo* and Byung Chul Park*** \\ Division of Animal Science, Gyeongsang National University*, \\ Regional Animal Industry Center, Jinju National University**, CJ Corp.***
}

\begin{abstract}
The present study was undertaken to investigate the effects of slaughter weight (SW) of finishing pigs fed a low-energy diet on growth efficiency and carcass quality and thereby to assess the optimal SW. (Yorkshire $\times$ Landrace) $\times$ Duroc-crossbred gilts and barrows were fed a diet containing $3,060 \mathrm{kcal} \mathrm{DE} / \mathrm{kg}$ from $80-\mathrm{kg} \mathrm{BW}$ and slaughtered at 110,125 , or $135 \mathrm{~kg}$, after which the belly, the most preferred cut in Korea, as well as the least preferred cuts ham and loin were subjected to physicochemical and sensory analyses. Both ADG and ADFI were greater $(\mathrm{P}<0.05)$ in the group slaughtered at 125 or $135 \mathrm{~kg}$ than in the $110-\mathrm{kg}-\mathrm{SW}$ group, whereas the opposite was true for gain:feed $(\mathrm{P}<0.01)$. Backfat thickness (BFT), which increased with increasing $\mathrm{SW}(\mathrm{P}<0.01$ and $\mathrm{P}<0.05)$, was greater in barrows than in gilts $(\mathrm{P}<0.01)$; BFT of barrows at $125 \mathrm{~kg}(24.6 \mathrm{~mm})$ was comparable to that of gilts at $135 \mathrm{~kg}(24.2 \mathrm{~mm})$. Physicochemical characteristics of the belly, ham and loin were minimally affected, if not affected, by SW; of note, however, the redness of the ham increased between 110- and 125-kg SW $(\mathrm{P}<0.05)$. In sensory evaluation of the belly, the fat:lean balance, which is a most important quality trait in this cut, was best $(\mathrm{P}<0.05)$ at $125 \mathrm{~kg}$ of $\mathrm{SW}$, but the overall acceptability of this cut was not changed by SW. In the ham and loin, the marbling score increased $(\mathrm{P}<0.01)$ between 110 - and $125-\mathrm{kg} \mathrm{SW}$, whereas color, aroma, off-flavor, and drip were unaffected by SW. In addition, the acceptability of the loin increased $(\mathrm{P}<0.05)$ between 110 - and $125-\mathrm{kg}$ SW. In cooked meats, none of color, aroma, off-flavor, juiciness, tenderness, taste, and acceptability was changed by SW, except for an increase $(\mathrm{P}<0.05)$ in darkness of loin color between $110-$ and $125-\mathrm{kg}$ SW. In conclusion, the optimal SW for the present subpopulation on the present low-energy diet lie in between 125 and $135 \mathrm{~kg}$ for gilts and at $125 \mathrm{~kg}$ for barrows.
\end{abstract}

(Key words : Finishing pig, Slaughter weight, Growth, Carcass, Meat quality)

\section{I. 서 론}

양돈산업에서 비육돈의 출하체중은 육질은 물론 수익에 영향을 미치는 매우 중요한 경제요인이다 $(\mathrm{Kim}$ 등, 2005; 이 등, 2006). 세계적으로 비육돈의 출하체중은 돼지의 유 전적 배경, 영양 및 사양관리 프로그램, 육가공업자 및 소 비자의 요구 등과 같은 내적, 외적 요인에 의해 결정된다 (Kim 등, 2005). 현재 국내 종돈은 대부분 유럽 및 미국에 서 수입해오는 적육형이나 국내 비육돈의 출하체중은 110 $\mathrm{kg}$ 정도로서 이들 나라에서의 출하체중보다 $5 \sim 15 \mathrm{~kg}$ 작 은 수치이다(Kim 등, 2005; NASS, 2008).
본 연구와 관련된 선행연구(이 등, 2006, 2007; 박 등, 2007)에서는 돼지 도체의 육량등급이 일차적으로 도체중 과 등지방두께에 의해 결정되는 현행 도체등급 판정 기준 (농림부, 2007) 하에서도 경제적 손실 없이 비육돈의 출하 체중을 $125 \mathrm{~kg}$ 까지 증가시킬 수 있음이 보고되었다. 또한 현행 육량등급 기준을 적용하지 않는다면 암퇘지와 거세 돼지를 각각 $110 \mathrm{~kg}$ 대비 135 및 $125 \mathrm{~kg}$ 까지 비육해도 지 방침착이 과다하지 않고 도체의 이화학적 특성 또한 110 $\mathrm{kg}$ 까지 비육했을 때에 비해 가시적인 차이가 없음이 이들 선행연구를 통해 밝혀졌다. 이들 연구에서는 생체중이 증 가함에 따른 과다한 지방침착을 방지하기 위해 비육돈사

Corresponding author : B. C. Park, C. J. Corp. 64 Shinheung-dong-3-ga, Incheon 400-103, Korea Tel: 032-881-2314, Fax: 032-881-2850, E-mail: bcpark@cj.net 
료의 에너지 수준을 NRC (1998)가 권장한 $3,400 \mathrm{kcal} \mathrm{DE} /$ $\mathrm{kg}$ 대비 $3,200 \mathrm{kcal} \mathrm{DE} / \mathrm{kg}$ 의 에너지를 함유한 사료를 사용 하였는데 (이 등, 2006, 2007) 사실상 이들 두 에너지 수준 은 비육돈의 성장률이나 지방침착에 미치는 효과에 있어 서 가시적인 차이를 보이지 않았다 (이 등, 2007). 따라서 비육돈사료의 에너지 수준을 낮춰 생체중 증가에 따른 지 방조직 성장률을 낮춤으로써 (Smith 등, 1999; Bee 등, 2002; Lee 등, 2002) 거세돼지와 암퇘지의 도살체중을 각 각 125 과 $135 \mathrm{~kg}$ 이상 비육할 수 있을지의 여부를 판단하 기 위해서는 비육돈사료의 에너지 수준과 성장과의 관계 에 관한 추가적인 연구가 필요하게 되었다. 또한 선행연 구에서는 국내에서 가장 선호되고 가장 비싼 부위인 삼겹 살을 비롯한 타 부분육의 육질 특성에 대한 조사가 매우 미흡하였다. 반면 최근 농림부 고시 (농림부, 2007)에 의해 돼지 도체는 육량등급과 병행하여 삼겹살의 품질 등에 의 해 결정되는 육질등급 기준이 적용되고 있기 때문에 육질 에 영향을 미치는 주요 변수를 최적화할 필요가 대두되 었다.

따라서 본 연구는 육질등급제가 본격적으로 적용되기 전인 2007년 가을 $3,060 \mathrm{kcal} \mathrm{DE} / \mathrm{kg}$ 의 저에너지 사료를 비 육돈에 급여했을 때 성장효율, 도체의 이화학적 특성 및 주요 부분육에 대한 관능평가 육질특성에 미치는 영향을 구명하여 적정 도살체중을 추정하고자 수행되었다.

\section{ㅍ. 재료 및 방법}

\section{1. 공시돈}

본 실험은 약 150 일령 된 $80.3 \pm 0.3 \mathrm{~kg}$ 의 적육형 (Yorkshire $\times$ Landrace $) \times$ Duroc 암퇘지와 거세돼지 각각 72 두씩 총 144 두를 이용하여 2 (성; 암 및 거세) $\times 3$ (도살체중; 110,125 및 $135 \mathrm{~kg}$ ) 요인분석 실험설계 하에 수행되었다. 본 실험목적을 달성하기 위해 $135 \mathrm{~kg}$ 에 도축될 24두의 암 퇘지와 24두의 거세돼지를 돈방당 6 두씩 각각 4돈방에 임 의로 배치하고 3 주 후에 $125 \mathrm{~kg}$ 에 도축될 암퇘지와 거세 돼지 총 48 두를 8 돈방에 배치한 다음 다시 3 주 후에는 $110 \mathrm{~kg}$ 에 도축될 공시돈 48 두를 종전과 같이 배치하여 짧 은 기간 내에 모든 공시돈이 도축될 수 있게 하였다. 공 시돈에게는 $1.1 \mathrm{~m}^{2}$ /두의 공간과 자유로이 접할 수 있는 음 용수 및 $\mathrm{NRC}(1998)$ 가 권장한 에너지 수준의 $90 \%$ 에 해당 하는 $3,060 \mathrm{kcal} \mathrm{DE} / \mathrm{kg}$ (Table 1)의 에너지를 함유한 저에 너지 사료가 제공되었다. 공시돈의 체중은 3 주 간격 및 출하 시에 측정하였다.

\section{2. 도축 및 부분육 분석}

공시돈이 정해진 출하체중에 도달하면 도축 전일 오후 에 부경양돈농협 축산물공판장으로 1.5 시간 동안 수송하 여 계류시킨 다음 이튿날 도축하고 도체는 $4^{\circ} \mathrm{C}$ 에서 24 시
Table 1. Composition of the diet (as-fed basis)

\begin{tabular}{lr}
\hline Item & Content \\
\hline \hline Ingredients, \% & \\
Corn & 54.33 \\
Wheat bran & 24.14 \\
Soybean meal (44\%) & 15.32 \\
Limestone & 0.74 \\
Dicalcium phosphate & 0.82 \\
Salt & 0.30 \\
Vitamin premix ${ }^{\mathrm{a}}$ & 0.10 \\
Mineral premix & 0.10 \\
Liquid molasses & 4.00 \\
L-lysine & 0.15 \\
\hline Calculated chemical composition & \\
DE, Mcal/kg & 3.06 \\
Crude protein, \% & 15.00 \\
Lysine, \% & 0.85 \\
Crude fat, \% & 2.98 \\
Crude fiber, \% & 4.25 \\
Crude ash, \% & 5.10 \\
Ca, \% & 0.65 \\
P, \% & 0.59 \\
\hline
\end{tabular}

\footnotetext{
${ }^{\mathrm{a}}$ Provided per $\mathrm{kg}$ of diet: 8,100 IU vitamin A, 1,200 IU vitamin $\mathrm{D}_{3}$, $45 \mathrm{IU}$ vitamin $\mathrm{E}, 2.25 \mathrm{mg}$ vitamin $\mathrm{K}, 1.5 \mathrm{mg}$ thiamin, 0.6 $\mathrm{mg}$ riboflavin, $2.55 \mathrm{mg}$ pyridoxine, $0.03 \mathrm{mg}$ vitamin $\mathrm{B}_{12}, 19.5$ $\mathrm{mg}$ pantothenic acid, $39 \mathrm{mg}$ niacin, $0.09 \mathrm{mg}$ biotin, and $0.75 \mathrm{mg}$ folic acid.

${ }^{\mathrm{b}}$ Provided per $\mathrm{kg}$ of diet: $102.7 \mathrm{mg} \mathrm{FeSO}_{4}, 0.442 \mathrm{mg} \mathrm{CoSO}, 67$ $\mathrm{mg} \mathrm{CuSO}$, $54.18 \mathrm{mg} \mathrm{MnSO}_{4}, 69 \mathrm{mg} \mathrm{ZnSO}_{4}, 0.546 \mathrm{mg} \mathrm{CaIO}_{3}$, and $0.338 \mathrm{mg} \mathrm{Na}_{2} \mathrm{SeO}_{3}$.
}

간 냉각시켰다. 등지방두께는 냉도체의 마지막 늑골과 요 추 사이 및 11 번과 12 번 늑골 사이에서 측정하여 (Lee 등, 2002; 박 등, 2007) NSIF (1997)가 제안한 방법에 따라 표 적체중 기준으로 측정치를 보정하였고, 부분육은 농림부 고시 (농림부, 2005)에 따라 냉도체로부터 분할하였다.

\section{3. 부분육의 이화학적 특성 분석}

임의로 선택된 특정일에 도축된 36 두의 공시돈 도체로 부터 삼겹살, 뒷다리 및 등심 각각 36쪽을 수거하여 이화 학적 특성 및 관능검사를 실시하였다. 이들 부분육에 대 한 근육 및 지방색은 CIE (1978) L*(명도), a* (적색도) 및 $\mathrm{b}^{*}$ (황색도) 기준으로 측정하였고, 수분, 조단백질 및 조지 방 함량은 $\mathrm{AOAC}$ (1990) 방법으로 측정하였으며, 24-h pH 는 Lee 등 $(2002,2005)$ 이 설명한 바와 같이 시료를 10 배 부피의 증류수로 균질화하여 측정하였다. 가열육의 보수 력은 원심분리법 (Wierbicki 등, 1956)으로 측정하였고, 뒷 다리와 등심 가열육의 전단가는 Warner-Bratzler 기구를 Universal Testing Machine (Instron, Canton, MA, USA)에 장 
착하여 측정하였다 (Yang 등, 2006).

\section{4. 관능검사}

부분육의 이화학적 특성 분석에 쓰인 36 두의 공시돈 중 임의로 선택된 18 두의 공시돈 (3두/실험구)으로부터 산출된 삼겹살, 뒷다리 및 등심 신선육과 가열육에 대한 육질은 경상대학교 육가공실험실에서 잘 훈련된 6인의 검사요원 에 의해 전술 (Moon 등, 2006; Yang 등, 2006)한 바와 같 이 9점 척도법[1 점 \{매우 나쁘거나 낮음 ("extremely bad or slight”) $\rightarrow$ 9점 \{매우 좋거나 강함(“extremely good or much")\}]으로 평가되었다. 신선육에 대해서는 육색, 향, 이 상취, 육즙참출 정도, 상강도 및 전체적인 기호도가 평가 되었고, $72^{\circ} \mathrm{C}$ 수조에서 30 분간 처리된 $5 \times 5 \times 3 \mathrm{~cm}$ 크기의 가열육에 대해서는 육색, 향, 이상취, 다즙성, 연도, 맛 및 기호도가 평가되었다.

\section{5. 통계분석}

모든 변수는 SAS (1996)의 General Linear Model Procedure를 이용하여 분석하였다. 이때 사료섭취량과 사료효율 은 돈방을 실험단위로 하고, 관능평가 변수를 포함한 그 외의 모든 변수에 대해서는 공시돈 [관능평가의 경우 성 $\times$ 도살체중에 'nested']을 실험단위로 하여 성, 도살체중 및 성×도살체중 간의 상호작용의 유의성 여부를 검정하였다.

\section{III. 결 과}

\section{1. 성장효율 및 부분육 수율}

개시체중과 종료체중은 표적 종료체중보다 실제 종료체 중이 2 3 kg 높았던 $135 \mathrm{~kg}$ 종료체중의 암퇘지 및 거세돼 지 구와 $125 \mathrm{~kg}$ 종료체중의 거세돼지 구를 제외한 모든 실험구에서 표적체중의 $\pm 1 \mathrm{~kg}$ 범위 내에 들었다 (Table 2). 일당증체량 $(\mathrm{ADG})$ 은 125 및 $135 \mathrm{~kg}$ 도살체중 구 $(0.83 \mathrm{~kg})$ 가 $110 \mathrm{~kg}$ 도살체중 구 $(0.77 \mathrm{~kg})$ 보다 컸으나 $(\mathrm{P}<0.05)$, 암퇘 지 $(0.80 \mathrm{~kg})$ 와 거세돼지 $(0.82 \mathrm{~kg})$ 간에는 차이가 없었다 $(\mathrm{P}=$ $0.36)$. 일당사료섭취량 $(\mathrm{ADFI})$ 은 125 및 $135 \mathrm{~kg}$ 도살체중 구 (각각 $3.74 \& 3.57 \mathrm{~kg}$ )가 $110 \mathrm{~kg}$ 구 $(2.90 \mathrm{~kg}$ ) 보다 컸다 $(\mathrm{P}<0.01)$. 그러나 본 변수는 성 $\times$ 도살체중 간의 상호작용 $(\mathrm{P}<0.05)$ 이 있어서 암퇘지에서는 $125 \mathrm{~kg}$ 도살체중 구와 $135 \mathrm{~kg}$ 구 간에 차이가 없었으나 거세돼지에서는 $125 \mathrm{~kg}$ 구가 $135 \mathrm{~kg}$ 및 $110 \mathrm{~kg}$ 구보다 본 변수의 크기가 컸다 (각 각 $\mathrm{P}<0.05$ 및 $\mathrm{P}<0.01)$. 반면 사료효율에 있어서는 전체 공 시돈 및 암퇘지에서는 $110 \mathrm{~kg}$ 도살체중 구가 125 및 135 $\mathrm{kg}$ 구보다 컸으나, 거세돼지에서는 $110 \mathrm{~kg}$ 구와 $135 \mathrm{~kg}$ 구 간 차이가 없었다 $(\mathrm{P}=0.30)$. 등지방두께는 예상되었던 대로 거세돼지 $(24.0 \mathrm{~mm})$ 가 암퇘지 $(20.9 \mathrm{~mm})$ 보다 컸고, 도살체 중이 $110 \mathrm{~kg}$ 에서 $125 \mathrm{~kg}$ 으로 증가하면서 본 변수 또한 증
가하였으며 (각각 $\quad 19.3$ 와 $\quad 23.0 \mathrm{~mm} ; \quad \mathrm{P}<0.01), \quad 135 \mathrm{~kg}(25.0$ $\mathrm{mm})$ 으로 증가하면서 또 증가하였다 $(\mathrm{P}<0.05)$.

도체율 (Table 3$)$ 은 암퇘지 $(75.0 \%)$ 가 거세돼지 (74.3\%) 보 다 높은 경향을 보였으나 유의차는 없었고 $(\mathrm{P}=0.10), 135$ $\mathrm{kg}$ 도살체중 구 (75.6\%)가 $125 \mathrm{~kg}(74.2 \%)$ 및 $110 \mathrm{~kg}(74.2 \%)$ 구보다 높았다 $(\mathrm{P}<0.01)$. 생체중 대비 7 개 주요부위의 무게 만을 합하여 계산한 정육율은 암퇘지 $(44.2 \%)$ 가 거세돼지 (41.4\%) 보다 높았고, 총 부분육 중량 대비 개별 부분육 중량 비율에 있어서는 단지 갈비 비율에서 거세돼지 $(8.6 \%)$ 가 암퇘지 $(8.2 \%)$ 보다 컸을 뿐 타 부위에서는 두 성 혹은 세 도살체중 구 간 차이가 없었다.

\section{2. 삼겹살, 뒷다리 및 등심의 이화학적 특성}

삼겹살 근육층과 지방층의 명도 $\left(\mathrm{L}^{*}\right)$ 및 근육층의 적색 도 $\left(\mathrm{a}^{*}\right)$ 는 두 성 혹은 세 도살체중 구 간 차이가 없었으나, 지방층의 황색도 $\left(\mathrm{b}^{*}\right)$ 는 암퇘지 (6.05)가 거세돼지 (5.48) 보 다 높았고 $(\mathrm{P}<0.05) 110 \mathrm{~kg}$ 도살체중 구 $(6.20)$ 가 $135 \mathrm{~kg}$ 구 (5.41) 보다 높았다 $(\mathrm{P}<0.05$; Table 4). 삼겹살의 $24-\mathrm{h} \mathrm{pH}$ 는 $135 \mathrm{~kg}$ 도살체중 구가 $110 \mathrm{~kg}$ 구보다 높았으나 $(\mathrm{P}<0.01)$, 이 들 두 구 간 수치상의 차이는 0.2 미만이었다. 본 부위의 수분 함량은 성별 혹은 도살체중 구별 차이가 없었고, 조 지방 함량은 출하체중 증가와 함께 증가하는 경향 $(\mathrm{P}=0.06)$ 이 있었다 $(110,125$ 및 $135 \mathrm{~kg}$ 도살체중 구: 각각 34.9 , 36.2 및 $39.8 \%)$.

뒷다리의 명도는 암퇘지 (50.6)가 거세돼지 (47.5) 보다 다소 높았고 $(\mathrm{P}<0.05)$, 적색도는 125 및 $135 \mathrm{~kg}$ 출하체중 구 (각각 11.08 와 10.89)가 $110 \mathrm{~kg}$ 구 (9.71) 보다 높았으나 $(\mathrm{P}<0.05) 125 \mathrm{~kg}$ 구와 $135 \mathrm{~kg}$ 구 간에는 차이가 없었다. 본 부위의 24-h pH, 보수력, 가열육에 대한 전단가, 수분, 조 지방 및 조단백질 함량은 성 혹은 도살체중의 영향을 받 지 않았으나, 가열감량은 거세돼지에서는 $138 \mathrm{~kg}$ 도살체중 구가 $110 \mathrm{~kg}$ 구에 비해 낮은 경향을 보였으나 $(\mathrm{P}=0.06)$ 암 퇘지에서는 도살체중 구간 주목할 만한 경향을 나타내지 않았다.

등심에서는 명도, 적색도, $\mathrm{pH}$, 보수력, 가열감량 및 전단 가에서 두 성 혹은 세 도살체중 구 간 차이가 없었고, 수 분함량은 $110 \mathrm{~kg}(74.7 \%)$ 과 $125 \mathrm{~kg}$ 도살체중 구 (74.1\%) 간 에는 차이가 없었으나, 전자는 $135 \mathrm{~kg}$ 구 $(73.7 \%)$ 보다 높 았다 $(\mathrm{P}<0.05)$. 조지방 함량에서는 두 성 혹은 세 도살체중 구 간 차이가 없었다. 본 부위의 조단백질 함량은 $135 \mathrm{~kg}$ 도살체중 구 $(21.7 \%)$ 가 $110 \mathrm{~kg}$ 구 $(20.9 \%)$ 보다 높았고, 이 들 두 구와 $125 \mathrm{~kg}$ 구 $(21.3 \%)$ 간에는 차이가 없었다.

\section{3. 관능평가}

관능평가단이 평가한 삼겹살 지방층 색깔의 세기 (“darkness”) 및 향의 세기는 $110 \mathrm{~kg}$ 과 $125 \mathrm{~kg}$ 도살체중 사이에 증가하 였으나 $(\mathrm{P}<0.05)$, 근육층의 색깔은 도살체중이 증가해도 변 
Park et al. ; Growth Efficiency and Carcass Quality of Larger Pigs

Table 2. Growth performance of finishing gilts and barrows slaughtered at different body weights

\begin{tabular}{|c|c|c|c|c|c|c|c|c|}
\hline \multirow{2}{*}{ Item } & \multicolumn{3}{|c|}{ Gilts } & \multicolumn{3}{|c|}{ Barrows } & \multirow{2}{*}{$\begin{array}{c}\text { Pooled } \\
\text { SE }\end{array}$} & \multirow{2}{*}{$\begin{array}{c}\text { Significance } \\
(\mathrm{S}, \mathrm{SW})^{\mathrm{a}}\end{array}$} \\
\hline & $110 \mathrm{~kg}$ & $125 \mathrm{~kg}$ & $135 \mathrm{~kg}$ & $110 \mathrm{~kg}$ & $125 \mathrm{~kg}$ & $135 \mathrm{~kg}$ & & \\
\hline Initial $\mathrm{wt}^{\mathrm{b}}, \mathrm{kg}$ & 80.5 & 80.0 & 80.2 & 80.6 & 80.6 & 79.9 & 0.8 & \\
\hline Final $\mathrm{wt}^{\mathrm{b}}, \mathrm{kg}$ & 109.5 & 125.2 & 137.3 & 109.6 & 129.3 & 137.8 & 0.8 & $\mathrm{~S}^{*}, \mathrm{SW}^{* *}, \mathrm{~S} \times \mathrm{SW}^{*}$ \\
\hline $\mathrm{ADG}^{\mathrm{b}}, \mathrm{kg}$ & 0.77 & 0.82 & 0.82 & 0.78 & 0.84 & 0.83 & 0.02 & $\mathrm{SW}^{*}$ \\
\hline $\mathrm{ADFI}^{\mathrm{c}}, \mathrm{kg}$ & 2.69 & 3.68 & 3.66 & 3.10 & 3.81 & 3.48 & 0.09 & $\mathrm{SW}^{* *}, \mathrm{~S} \times \mathrm{SW}^{*}$ \\
\hline Gain:feed $^{\mathrm{c}}$ & 0.280 & 0.223 & 0.223 & 0.248 & 0.219 & 0.238 & 0.006 & $\mathrm{SW}^{* *}, \mathrm{~S} \times \mathrm{SW}^{* *}$ \\
\hline Backfat $^{b, d}, \mathrm{~mm}$ & 17.1 & 21.3 & 24.2 & 21.5 & 24.6 & 25.8 & 1.0 & $\mathrm{~S}^{* *}, \mathrm{SW}^{* *}$ \\
\hline
\end{tabular}

${ }^{a} \mathrm{~S}$, sex; SW, slaughter weight.

${ }^{b}$ Data are means of 24 animals in each $\mathrm{S} \times \mathrm{SW}$ combination.

c Pen was the experimental unit $(\mathrm{n}=4$ in each $\mathrm{S} \times \mathrm{SW}$ combination).

${ }^{d}$ Targeted SW-adjusted average of the measurements between the $11^{\text {th }}$ and $12^{\text {th }}$ ribs and between the last rib and the $1^{\text {st }}$ lumbar.

* $\mathrm{P}<0.05$. ** $\mathrm{P}<0.01$.

Table 3. Yields of primal cuts of finishing gilts and barrows slaughtered at different body weights

\begin{tabular}{|c|c|c|c|c|c|c|c|c|}
\hline \multirow{2}{*}{ Item } & \multicolumn{3}{|c|}{ Gilts } & \multicolumn{3}{|c|}{ Barrows } & \multirow{2}{*}{$\begin{array}{c}\text { Pooled } \\
\text { SE }\end{array}$} & \multirow{2}{*}{$\begin{array}{c}\text { Significance } \\
(\mathrm{S}, \mathrm{SW})^{\mathrm{a}}\end{array}$} \\
\hline & $110 \mathrm{~kg}$ & $125 \mathrm{~kg}$ & $135 \mathrm{~kg}$ & $110 \mathrm{~kg}$ & $125 \mathrm{~kg}$ & $135 \mathrm{~kg}$ & & \\
\hline$\overline{\text { Carcass } \mathrm{wt}^{\mathrm{b}}, \mathrm{kg}}$ & 81.4 & 94.0 & 103.9 & 81.2 & 94.8 & 104.1 & 0.8 & $\mathrm{SW}^{* *}$ \\
\hline Dressing $^{\mathrm{b}}, \%$ & 74.3 & 75.1 & 75.6 & 74.1 & 73.4 & 75.5 & 0.5 & $\mathrm{SW}^{* *}$ \\
\hline Total primal $\mathrm{wt}^{\mathrm{c}}, \mathrm{kg}$ & 49.8 & 55.1 & 59.2 & 45.3 & 53.1 & 56.0 & 1.2 & $\mathrm{~S}^{* *}, \mathrm{SW}^{* *}$ \\
\hline Primal yield ${ }^{\mathrm{c}}, \%$ & 45.1 & 44.2 & 43.2 & 41.9 & 41.4 & 41.1 & 0.9 & $\mathrm{~S}^{* *}$ \\
\hline \multicolumn{9}{|l|}{ Primal cut percentage ${ }^{c}$} \\
\hline Shoulder & 16.2 & 16.0 & 16.1 & 16.9 & 16.1 & 15.7 & 0.5 & \\
\hline Neck & 8.6 & 8.4 & 8.5 & 7.7 & 8.4 & 8.6 & 0.2 & \\
\hline Loin & 12.9 & 12.8 & 12.6 & 12.1 & 12.5 & 12.2 & 0.3 & \\
\hline Tenderloin & 2.0 & 1.8 & 1.8 & 1.8 & 1.7 & 1.8 & 0.1 & \\
\hline Rib & 8.1 & 8.1 & 8.4 & 8.4 & 8.4 & 8.9 & 0.2 & $\mathrm{~S}^{*}$ \\
\hline Belly & 20.0 & 21.4 & 20.6 & 21.1 & 21.0 & 21.8 & 0.5 & \\
\hline Ham & 32.2 & 31.7 & 32.0 & 31.9 & 31.9 & 31.0 & 0.5 & \\
\hline Total & 100.0 & 100.0 & 100.0 & 100.0 & 100.0 & 100.0 & 100.0 & \\
\hline
\end{tabular}

a S, sex; SW, slaughter weight.

b Data are means of 24 observations in each $\mathrm{S} \times \mathrm{SW}$ combination.

c Data are means of six animals in each $\mathrm{S} \times \mathrm{SW}$ combination. Live weights of the six groups beginning from $110-\mathrm{kg}$ gilts to $135-\mathrm{kg}$ barrows were $110.2,124.8,137.3,108.3,128.3$, and $136.3 \mathrm{~kg}$, respectively, with pooled $\mathrm{SE}=1.4 \mathrm{~kg}$.

* $\mathrm{P}<0.05$. ** $\mathrm{P}<0.01$.

하지 않았고, 이상취는 암퇘지보다 거세돼지에서 높았다 $(\mathrm{P}<0.05$; Table 5). 지방층 : 근육층 두께의 비율은 $110 \mathrm{~kg}$ 과 $125 \mathrm{~kg}$ 도살체중 사이 증가하였으나 $(\mathrm{P}<0.05), 125 \mathrm{~kg}$ 과 135 $\mathrm{kg}$ 사이에서는 변하지 않았다 $(\mathrm{P}=0.28 ; 110,125$ 및 $135 \mathrm{~kg}$ 도살체중 시 각각 $4.53,5.34$ 및 5.69). 지방층:근육층 두께 의 균형은 $125 \mathrm{~kg}$ 도살체중 구(5.53)가 $110 \mathrm{~kg}(4.85)$ 및 $135 \mathrm{~kg}$ (4.87) 구에 비해 높았다 $(\mathrm{P}<0.05)$. 그러나 삼겹살의 전체적인 기호도는 도살체중이 증가하여도 변하지 않았다. 뒷다리 신선육에 대한 색깔, 향, 이상취 및 육즙참출 정 도는 두 성 및 세 도살체중 구 간 차이가 없었다. 상강도 는 $125 \mathrm{~kg}$ (4.17) 및 $135 \mathrm{~kg}$ (4.35) 도살 시 $110 \mathrm{~kg}(2.92)$ 도 살시에 비해 월등히 향상되었으나 $(\mathrm{P}<0.01)$, 전체적인 기호 도에 있어서는 세 도살체중 구 간 차이가 없었다.
등심 신선육의 색깔, 향, 이상취 및 육즙참출 정도는 두 성 혹은 세 도살체중 구 간 차이가 없었다. 반면 등심의 상강도는 뒷다리에서와 같이 체중 $110 \sim 125 \mathrm{~kg}$ 사이 증가 하였으나 $(\mathrm{P}<0.01) 125 \mathrm{~kg}$ 이후에는 더 이상 증가하지 않았 다 $(110,125$ 및 $135 \mathrm{~kg}$ 구의 상강도: $2.69,4.14$ 및 4.60). 또한 본 변수는 암퇘지에서는 $110 \mathrm{~kg}$ 과 $125 \mathrm{~kg}$ 도살체중 사이에서만 증가한 반면 거세돼지에서는 $110 \mathrm{~kg}$ 과 $125 \mathrm{~kg}$ 사이에서는 증가하는 경향 $(\mathrm{P}=0.06)$ 이 있었고 $125 \mathrm{~kg}$ 과 $135 \mathrm{~kg}$ 사이에서는 유의적으로 증가하였다 $(\mathrm{P}<0.01)$. 본 부 분육의 전체적인 기호도는 $110 \mathrm{~kg}$ 과 $125 \mathrm{~kg}$ 도살체중 사이 에서는 증가하였으나 $(\mathrm{P}<0.05) 125 \mathrm{~kg}$ 과 $135 \mathrm{~kg}$ 사이에서는 변하지 않았다 $(110,125$ 및 $135 \mathrm{~kg}$ 도살체중 시 각각 4.17, 4.83 및 4.94). 
Table 4. Physicochemical characteristics of the belly, ham, and loin of finishing gilts and barrows at different slaughter weights

\begin{tabular}{|c|c|c|c|c|c|c|c|c|}
\hline \multirow{2}{*}{ Item } & \multicolumn{3}{|c|}{ Gilts } & \multicolumn{3}{|c|}{ Barrows } & \multirow{2}{*}{$\begin{array}{l}\text { Pooled } \\
\text { SE }\end{array}$} & \multirow{2}{*}{$\begin{array}{l}\text { Significance } \\
\quad(\mathrm{S}, \mathrm{SW})^{\mathrm{a}}\end{array}$} \\
\hline & $110 \mathrm{~kg}$ & $125 \mathrm{~kg}$ & $135 \mathrm{~kg}$ & $110 \mathrm{~kg}$ & $125 \mathrm{~kg}$ & $135 \mathrm{~kg}$ & & \\
\hline \multicolumn{9}{|c|}{ Belly $^{b}$} \\
\hline CIE L*(muscle) & 44.6 & 45.3 & 45.7 & 45.6 & 46.1 & 42.6 & 1.12 & \\
\hline CIE L* (fat) & 79.1 & 79.4 & 79.0 & 79.7 & 79.9 & 79.4 & 0.65 & \\
\hline CIE $a^{*}$ (muscle) & 15.09 & 14.96 & 15.30 & 14.34 & 14.94 & 14.10 & 0.74 & \\
\hline CIE b* (fat) & 6.56 & 5.80 & 5.80 & 5.83 & 5.60 & 5.01 & 0.30 & $\mathrm{~S}^{*}, \mathrm{SW}^{*}$ \\
\hline $24 \mathrm{~h} \mathrm{pH}$ (muscle) & 6.28 & 6.36 & 6.38 & 6.28 & 6.32 & 6.51 & 0.06 & $\mathrm{SW}^{*}$ \\
\hline Moisture, \% & 46.8 & 44.5 & 41.7 & 42.1 & 45.5 & 43.1 & 2.66 & \\
\hline Crude fat, $\%$ & 34.6 & 37.6 & 41.3 & 35.2 & 34.8 & 38.2 & 2.66 & \\
\hline \multicolumn{9}{|c|}{$\underline{\text { Ham }}^{b}$} \\
\hline $\mathrm{L}^{*}$ & 50.5 & 49.8 & 51.5 & 49.7 & 48.5 & 44.2 & 1.51 & $\mathrm{~S}^{*}$ \\
\hline$a^{*}$ & 9.54 & 11.53 & 10.93 & 9.88 & 10.64 & 10.86 & 0.52 & $\mathrm{SW}^{*}$ \\
\hline $24 \mathrm{~h} \mathrm{pH}$ & 5.72 & 5.90 & 5.77 & 5.75 & 5.88 & 5.85 & 0.07 & \\
\hline $\mathrm{WHC}^{\mathrm{c}}, \%$ & 55.4 & 55.3 & 52.0 & 59.5 & 53.5 & 53.2 & 2.1 & \\
\hline Cooking loss, \% & 38.2 & 37.8 & 40.1 & 39.8 & 39.2 & 36.8 & 1.1 & $\mathrm{~S} \times \mathrm{SW}^{*}$ \\
\hline Shear force ${ }^{\mathrm{d}}, \mathrm{kg} / \mathrm{cm}^{2}$ & 3.59 & 2.63 & 4.30 & 3.19 & 3.34 & 3.38 & 0.51 & \\
\hline Moisture, \% & 75.6 & 75.6 & 74.3 & 75.3 & 75.1 & 75.1 & 0.40 & \\
\hline Crude fat, $\%$ & 1.75 & 1.85 & 2.53 & 2.26 & 1.88 & 2.04 & 0.20 & \\
\hline Crude protein, \% & 21.1 & 21.1 & 22.0 & 21.2 & 21.3 & 21.3 & 0.32 & \\
\hline \multicolumn{9}{|c|}{ Loin $^{b}$} \\
\hline CIE L* & 53.5 & 54.3 & 53.4 & 52.5 & 54.5 & 52.0 & 1.34 & \\
\hline CIE $a^{*}$ & 6.93 & 8.12 & 7.17 & 6.95 & 7.43 & 7.30 & 0.54 & \\
\hline $24 \mathrm{~h} \mathrm{pH}$ & 5.67 & 5.68 & 5.61 & 5.70 & 5.68 & 5.70 & 0.04 & \\
\hline $\mathrm{WHC}^{\mathrm{c}}, \%$ & 55.4 & 54.5 & 58.5 & 58.3 & 57.3 & 54.4 & 2.1 & \\
\hline Cooking loss, $\%$ & 35.7 & 36.1 & 37.3 & 36.3 & 36.8 & 34.3 & 1.7 & \\
\hline Shear force ${ }^{\mathrm{d}}, \mathrm{kg} / \mathrm{cm}^{2}$ & 3.20 & 3.05 & 3.34 & 3.15 & 3.21 & 3.03 & 0.32 & \\
\hline Moisture, \% & 74.8 & 74.1 & 73.9 & 74.6 & 74.1 & 73.5 & 0.32 & $\mathrm{SW}^{*}$ \\
\hline Crude fat, $\%$ & 1.73 & 2.13 & 1.85 & 1.92 & 2.05 & 2.47 & 0.27 & \\
\hline Crude protein, \% & 20.8 & 21.3 & 21.6 & 21.1 & 21.3 & 21.9 & 0.25 & $\mathrm{SW}^{*}$ \\
\hline
\end{tabular}

${ }^{a} \mathrm{~S}$, sex; SW, slaughter weight.

b Data are means of six animals in each $\mathrm{S} \times \mathrm{SW}$ combination. Fresh cut was used, unless indicated otherwise.

c WHC, water-holding capacity. ${ }_{\mathrm{d}}$ Measured on cooked meat. $* \mathrm{P}<0.05$.

Table 6은 가열육에 대한 관능평가 결과이다. 삼겹살의 연도는 암퇘지보다 거세돼지에서 약간 높았고 $(\mathrm{P}<0.05)$ 등 심의 색깔은 $110 \mathrm{~kg}$ 도축 시보다 $125 \mathrm{~kg}$ 도축 시에 진하였 으나 $(\mathrm{P}<0.05)$ 이들 두 경우를 제외하면 색깔, 향, 이상취, 다즙성, 연도, 맛 및 전체적인 기호도에서 두 성 및 세 도 살체중 구 간 차이가 없었다:

\section{$\mathrm{IV}$. 고 찰}

전체적으로 본 연구에서 얻은 암퇘지와 거세돼지의 등 지방두께를 포함한 성별 및 도살체중별 상대적인 성장성 적은 이 등 (2006)과 박 등 (2007)의 선행연구 결과 및 타 연구진 (Cisneros 등, 1996; Leach 등, 1996; Latorre 등, 2004)이 $100 \sim 160 \mathrm{~kg}$ 생체중 범위에서 얻은 결과와도 유사
하였다. 본 연구에서 타 도살체중 구에 비해 $110 \mathrm{~kg}$ 구의 일당증체량이 약간 낮았던 결과는 다소 이례적이기는 하 였으나, 이들 결과는 Cisneros 등 (1996)이 주장한 바와 같 이 유전적으로 현대 비육돈의 성장성적은 도살체중의 영 향이 크지 않음을 시사한다. 그러나 등지방두께를 기준으 로 도체품질을 고려한다면 본 연구에 쓰인 저에너지 사료 $(3,060 \mathrm{kcal} \mathrm{DE} / \mathrm{kg})$ 를 급여했을 때 암퇘지와 거세돼지의 최 대 도살체중은 선행연구에서 $3,200 \mathrm{kcal} \mathrm{DE} / \mathrm{kg}$ 의 에너지 수준의 사료를 급여했을 때와 같이 각각 135 및 $125 \mathrm{~kg}$ 수준이었다. 따라서 암퇘지와 거세돼지의 도살체중을 이 들 수치보다 높일 수 있는 비육후기 사료의 에너지 수준 을 찾아내기 위해서는 추가의 연구가 요망된다.

본 연구에서 관찰된 도살체중 증가에 따른 도체율 증가, 거세돼지 대비 암퇘지의 높은 부분육 수율 및 도살체중과 
Table 5. Sensory quality traits of the fresh belly, ham, and loin of finishing gilts and barrows at different slaughter weights

\begin{tabular}{|c|c|c|c|c|c|c|c|c|}
\hline \multirow{2}{*}{ Item } & \multicolumn{3}{|c|}{ Gilts } & \multicolumn{3}{|c|}{ Barrows } & \multirow{2}{*}{$\begin{array}{c}\text { Pooled } \\
\text { SE }\end{array}$} & \multirow{2}{*}{$\begin{array}{c}\text { Significance } \\
(\mathrm{S}, \mathrm{SW})^{\mathrm{a}}\end{array}$} \\
\hline & $110 \mathrm{~kg}$ & $125 \mathrm{~kg}$ & $135 \mathrm{~kg}$ & $110 \mathrm{~kg}$ & $125 \mathrm{~kg}$ & $135 \mathrm{~kg}$ & & \\
\hline \multicolumn{9}{|c|}{ Belly $^{b}$} \\
\hline Color (fat) & 4.07 & 5.02 & 4.77 & 4.68 & 4.73 & 5.28 & 0.22 & $\mathrm{SW}^{*}$ \\
\hline Color (muscle) & 5.37 & 5.64 & 5.51 & 5.26 & 5.49 & 5.69 & 0.28 & \\
\hline Aroma & 3.13 & 3.68 & 3.72 & 3.00 & 3.92 & 4.19 & 0.34 & $\mathrm{SW}^{*}$ \\
\hline Off-flavor ${ }^{c}$ & 1.85 & 0.65 & 0.45 & 1.68 & 2.62 & 1.93 & 0.62 & $\mathrm{~S}^{*}$ \\
\hline Fat:lean ratio & 4.23 & 5.54 & 5.34 & 4.85 & 5.15 & 6.04 & 0.32 & $\mathrm{SW}^{* *}$ \\
\hline Fat:lean balance & 4.42 & 5.53 & 5.01 & 5.27 & 5.52 & 4.73 & 0.24 & $\mathrm{SW}^{*}$ \\
\hline Acceptability & 4.62 & 5.19 & 4.86 & 4.94 & 5.07 & 4.65 & 0.23 & \\
\hline \multicolumn{9}{|c|}{$\underline{\text { Ham }}^{\text {b }}$} \\
\hline Color & 5.52 & 5.64 & 5.18 & 5.18 & 5.87 & 5.97 & 0.38 & \\
\hline Aroma & 4.70 & 4.55 & 4.72 & 4.59 & 4.93 & 4.88 & 0.18 & \\
\hline Off-flavor & 1.62 & 1.63 & 1.53 & 1.62 & 1.73 & 1.58 & 0.18 & \\
\hline Drip $^{c}$ & 4.84 & 4.82 & 4.89 & 4.76 & 4.48 & 5.14 & 0.21 & \\
\hline Marbling & 2.75 & 4.30 & 3.92 & 3.09 & 4.04 & 4.77 & 0.34 & $\mathrm{SW}^{* *}$ \\
\hline Acceptability & 3.59 & 4.17 & 3.80 & 3.82 & 4.12 & 4.72 & 0.24 & \\
\hline \multicolumn{9}{|c|}{ Loin $^{b}$} \\
\hline Color & 5.36 & 5.76 & 5.82 & 5.50 & 5.97 & 6.02 & 0.37 & \\
\hline Aroma & 4.68 & 5.85 & 4.77 & 4.71 & 4.58 & 4.51 & 0.28 & \\
\hline Off-flavor & 3.19 & 2.90 & 3.04 & 3.06 & 2.87 & 2.53 & 0.22 & \\
\hline Drip & 4.43 & 4.75 & 4.45 & 4.37 & 4.66 & 4.12 & 0.30 & \\
\hline Marbling & 2.51 & 4.43 & 3.77 & 2.87 & 3.86 & 5.44 & 0.36 & $\mathrm{SW}^{* *}, \mathrm{~S} \times \mathrm{SW}^{*}$ \\
\hline Acceptability & 4.13 & 4.83 & 4.41 & 4.20 & 4.82 & 5.46 & 0.26 & $\mathrm{SW}^{*}$ \\
\hline
\end{tabular}

${ }^{\text {a }}$ S, sex; SW, slaughter weight.

b Evaluated by four to six sensory panelists according to a 9-point hedonic scale. Greater values indicate "darker," "stronger," "superior," and "greater" in color, aroma, fat:lean balance/acceptability, and fat:lean ratio/marbling, respectively. Data are means of three animals in each $\mathrm{S} \times \mathrm{SW}$ combination.

"Greater values indicate "more" meaning "worse" in terms of quality.

* $\mathrm{P}<0.05$. ** $\mathrm{P}<0.01$.

성 (性)이 등심의 이화학적 특성에 거의 영향을 미치지 않 았던 결과는 기 보고된 결과 (Cisneros 등, 1996; Leach 등, 1996; Latorre 등, 2004; 이 등, 2006; 박 등, 2007)와 흡사 하였다. 그러나 본 연구에서 관찰된 도살체중 증가에 따 른 등심의 수분 함량 감소와 단백질 함량 증가는 종전에 는 일부 연구에서만 관찰되었기 (Cisneros 등, 1996; 박 등, 2007) 때문에 이들 변수 간의 관계는 향후 연구서도 계속 적으로 주시할 필요가 있다. 본 연구에서는 또한 적색도 와 $\mathrm{pH}$ 를 제외한 뒷다리와 삼겹살의 이화학적 특성이 도살 체중의 영향을 받지 않음이 밝혀졌다. 이와 관련하여 110 $\mathrm{kg}$ 과 $125 \mathrm{~kg}$ 도살체중 사이 뒷다리의 적색도 증가는 일종 의 도체 품질 향상으로 간주되어야 마땅하고, 도살체중 변화에 따른 삼겹살의 $\mathrm{pH}$ 변화는 비록 통계적으로는 유의 성이 있었으나 도살체중 간 절대수치 상의 차이가 작았기 때문에 생화학적으로 큰 의미를 부여할 수는 없을 것이다. 도살체중 증가에 따른 삼겹살의 근육층 대비 지방층 비 율 (fat: lean)의 증가는 도살체중 $125 \mathrm{~kg}$ 까지는 지방층:근육 층 비율 균형에 대한 관능평가점을 향상시켰지만 도살체
중을 $135 \mathrm{~kg}$ 까지 증가시키면 오히려 본 육질변수에 부의 영향을 미쳤다. 이 같은 결과는 비록 삼겹살의 전체적인 기호도와 타 관능 품질 특성이 도살체중과 무관하거나 단 지 극미한 영향만을 받았지만, $125 \mathrm{~kg}$ 을 정점으로 도살체 중이 증가하면 삼겹살의 품질이 낮게 평가될 수도 있음을 시사한다. 또한 뒷다리와 등심의 상강도와 등심의 전체적 인 기호도는 도살체중 $110 \mathrm{~kg}$ 과 $125 \mathrm{~kg}$ 사이 증가한 반면 본 연구에서 조사된 타 관능적 품질 특성은 도살체중의 영향을 받지 않았다. 따라서 이러한 결과를 비추어 볼 때 도살체중을 $110 \mathrm{~kg}$ 에서 $125 \mathrm{~kg}$ 으로 증가시키면 전체적인 도체품질이 향상됨이 자명해 진다. 한편 삼겹살, 뒷다리 및 등심 가열육에 대한 관능평가 품질특성은 도살체중의 영향을 거의 받지 않았는데 이는 $110 ~ 140 \mathrm{~kg}$ 도살체중 범 위에서 등심의 관능품질 특성이 도살체중과 거의 무관하 였던 Leach 등 (1996)의 결과와도 흡사하였다. 이상을 종합 하면 이들 결과는 도살체중 $110 \mathrm{~kg}$ 부터 $135 \sim 140 \mathrm{~kg}$ 까지에 서 돼지고기를 먹을 때 느끼는 질감 즉 'eating quality'는 도살체중의 영향을 받지 않음을 시사한다. 
Table 6. Sensory quality traits of the cooked belly, ham, and loin of finishing gilts and barrows at different slaughter weights

\begin{tabular}{|c|c|c|c|c|c|c|c|c|}
\hline \multirow{2}{*}{ Item } & \multicolumn{3}{|c|}{ Gilts } & \multicolumn{3}{|c|}{ Barrows } & \multirow{2}{*}{$\begin{array}{c}\text { Pooled } \\
\text { SE } \\
\end{array}$} & \multirow{2}{*}{$\begin{array}{l}\text { Significance } \\
(\mathrm{S}, \mathrm{SW})^{\mathrm{a}}\end{array}$} \\
\hline & $110 \mathrm{~kg}$ & $125 \mathrm{~kg}$ & $135 \mathrm{~kg}$ & $110 \mathrm{~kg}$ & $125 \mathrm{~kg}$ & $135 \mathrm{~kg}$ & & \\
\hline \multicolumn{9}{|c|}{ Belly $^{b}$} \\
\hline Aroma & 5.37 & 5.43 & 5.31 & 5.74 & 6.06 & 5.11 & 0.32 & \multirow{6}{*}{$\mathrm{S}^{*}$} \\
\hline Off-flavor $^{c}$ & 2.46 & 2.30 & 2.32 & 2.35 & 2.35 & 2.62 & 0.34 & \\
\hline Juiciness & 4.86 & 5.28 & 4.91 & 5.08 & 5.27 & 5.92 & 0.25 & \\
\hline Tenderness & 4.87 & 5.45 & 4.91 & 5.34 & 5.25 & 6.12 & 0.28 & \\
\hline Taste & 5.37 & 5.29 & 5.34 & 5.58 & 5.85 & 5.50 & 0.27 & \\
\hline Acceptability & 4.79 & 5.12 & 5.09 & 5.10 & 5.53 & 5.56 & 0.28 & \\
\hline \multicolumn{9}{|c|}{$\underline{\text { Ham }}^{b}$} \\
\hline Color & 4.99 & 4.92 & 4.56 & 4.82 & 4.67 & 4.92 & 0.31 & \\
\hline Aroma & 4.80 & 4.65 & 4.57 & 4.14 & 5.15 & 4.41 & 0.34 & \\
\hline Off-flavor & 3.15 & 2.96 & 2.91 & 3.02 & 2.88 & 3.47 & 0.33 & \\
\hline Juiciness & 4.70 & 4.89 & 4.35 & 4.81 & 5.17 & 5.94 & 0.43 & \\
\hline Tenderness & 3.97 & 4.66 & 4.40 & 4.43 & 5.05 & 5.75 & 0.52 & \\
\hline Acceptability & 4.49 & 4.74 & 4.57 & 4.55 & 5.10 & 5.34 & 0.42 & \\
\hline \multicolumn{9}{|c|}{ Loin $^{b}$} \\
\hline Color & 4.73 & 5.38 & 4.94 & 4.63 & 5.76 & 5.37 & 0.31 & $\mathrm{SW}^{*}$ \\
\hline Aroma & 4.70 & 5.17 & 4.91 & 4.94 & 4.93 & 4.76 & 0.30 & \\
\hline Off-flavor & 2.49 & 2.79 & 2.79 & 2.91 & 2.60 & 2.44 & 0.33 & \\
\hline Juiciness & 3.80 & 4.19 & 3.66 & 4.28 & 4.29 & 4.20 & 0.38 & \\
\hline Tenderness & 4.27 & 4.96 & 3.76 & 4.65 & 4.68 & 4.69 & 0.33 & \\
\hline Acceptability & 5.04 & 5.37 & 4.51 & 5.00 & 5.35 & 5.28 & 0.25 & \\
\hline
\end{tabular}

${ }^{a} \mathrm{~S}$, sex; SW, slaughter weight.

b Evaluated by four to six sensory panelists according to a 9-point hedonic scale. Greater values indicates "stronger," "darker," and more/superior in aroma, color, and juiciness/tenderness/taste/acceptability, respectively. Data are means of three animals in each $\mathrm{S} \times \mathrm{SW}$ combination.

c A greater value indicates "more" meaning "worse" in terms of quality. $\quad * \mathrm{P}<0.05$.

결론적으로, 본 연구에 쓰인 $3,060 \mathrm{kcal} \mathrm{DE} / \mathrm{kg}$ 수준의 저 에너지 비육돈사료를 급여할 때 암퇘지와 거세돼지의 도 살체중을 $110 \mathrm{~kg}$ 으로 부터 $125 \mathrm{~kg}$ 으로 증가시킴으로써 도 체품질을 향상시킬 수 있다. 또한 암퇘지에서는 도살체중 $125 \mathrm{~kg}$ 과 $135 \mathrm{~kg}$ 간에 도살체중 증가가 성장효율과 도체 품질 특성에 미치는 영향이 극미하기 때문에 시장 상황에 따라서는 도살체중을 $125 \mathrm{~kg}$ 이상 $135 \mathrm{~kg}$ 까지도 증가시킬 수도 있을 것이나, 거세돼지는 생체중 $125 \mathrm{~kg}$ 이후에는 체 지방 침착이 과다해지기 때문에 $125 \mathrm{~kg}$ 이 적정·한계 도살 체중인 것으로 사료된다. 그러나 사료의 에너지 수준이 성장효율과 도체 품질 특성에 미치는 영향을 규명하기 위 해서는 추가의 연구가 요망된다.

$$
\text { V. 요 약 }
$$

본 실험은 비육돈에 저에너지 사료를 급여했을 때 도살 체중이 성장효율과 도체 품질에 미치는 영향을 조사하여 적정 도살체중을 추정할 목적으로 수행되었다. (Yorkshire $\times$ Landrace) $\times$ Duroc 교잡종 암퇘지와 거세돼지에게 3,060 $\mathrm{kcal} \mathrm{DE} / \mathrm{kg}$ 의 저에너지사료를 생체중 $80 \mathrm{~kg}$ 부터 급여하여
110,125 , 혹은 $135 \mathrm{~kg}$ 에 도살한 다음 한국에서 선호도가 가장 높은 부위인 삼겹살과 선호도가 가장 낮은 뒷다리 및 등심에 대한 이화학적 특성과 관능검사를 실시하였다. 일당증체량과 일당사료섭취량은 공히 125 및 $135 \mathrm{~kg}$ 구가 $110 \mathrm{~kg}$ 구보다 높았고, 사료효율은 반대로 $110 \mathrm{~kg}$ 구가 높 았다 $(\mathrm{P}<0.01)$. 등지방두께는 도살체중이 증가하면서 증가 하였고 $(\mathrm{P}<0.01$ 와 $\mathrm{P}<0.05)$, 암퇘지보다 거세돼지에서 높아 $(\mathrm{P}<0.01) 125 \mathrm{~kg}$ 거세돼지의 등지방두께 $(24.6 \mathrm{~mm})$ 는 $135 \mathrm{~kg}$ 암퇘지의 수치 $(24.2 \mathrm{~mm})$ 와 비슷하였다. 삼겹살, 뒷다리 및 등심의 이화학적 특성은 도살체중의 영향을 거의 받지 않 았으나, $110 \mathrm{~kg}$ 과 $125 \mathrm{~kg}$ 도살체중 사이 뒷다리의 적색도 증가 $(\mathrm{P}<0.05)$ 는 주목할만 하였다. 삼겹살에 대한 관능평가 에서는 이 부위의 매우 중요한 품질 특성인 지방층:근육 층 비율이 $125 \mathrm{~kg}$ 도살체중에서 가장 높았으나 $(\mathrm{P}<0.05)$ 전 체적인 기호도는 도살체중과 무관하였다. 뒷다리와 등심 부위에서는 상강도는 $110 \mathrm{~kg}$ 과 $125 \mathrm{~kg}$ 도살체중 사이 증가 한 $(\mathrm{P}<0.01)$ 반면 색깔, 향, 이상취 및 육즙참출 정도는 도 살체중의 영향을 받지 않았다. 또한 등심 부위의 전체적 인 기호도는 $110 \mathrm{~kg}$ 과 $125 \mathrm{~kg}$ 도살체중 사이 증가하였다 $(\mathrm{P}<0.05)$. 가열육에 대한 관능평가에서는 $110 \mathrm{~kg}$ 과 $125 \mathrm{~kg}$ 
도살체중 사이에 등심 색깔이 진해진 $(\mathrm{P}<0.05)$ 경우 외에 는 색깔, 향, 이상취, 다즙성, 연도, 맛 및 전체적인 기호 도 중 어느 품질 특성도 출하체중 변화로 인해 변하지 않 았다. 결론적으로, 본 연구에 쓰인 저에너지 사료를 급여 할 때 본 연구에 쓰인 돈군의 암퇘지와 거세돼지의 적정 도살체중은 각각 $125 \sim 135 \mathrm{~kg}$ 및 $125 \mathrm{~kg}$ 수준이다.

$$
\text { VI. 사 사 }
$$

본 연구는 지식경제부/한국산업기술평가원, 씨제이제일 제당주식회사 및 태원농장이 지원한 진주산업대학교 동물 생명산업센터의 연구개발과제 사업비 지원으로 수행되었 습니다. 저자 일동은 공시사료 생산과 도체분석에 도움을 주신 부경양돈농협 사료사업본부 및 육가공사업본부 관계 자 여러분들과 부분육에 대한 이화학적 특성 분석과 관능 평가에 참가한 경상대학교 식육과학연구실 대학원생 및 연구원들께 감사드립니다.

\section{VII. 인 용 문 헌}

1. AOAC. 1990. Official Methods of Analysis. 15th ed. Assoc. Offic. Anal. Chem., Arlington, VA, USA.

2. Bee, G., Gebert, S. and Messikommer, R. 2002. Effect of dietary supply and fat source on the fatty acid pattern of adipose and lean tissues and lipogenesis in the pig. J. Anim. Sci. 80:1564-1574.

3. CIE. 1978. Recommendations on uniform color spaces-color difference equations, psychometric color terms. Supplement no. 2 to CIE Publication No. 15 (E-1.3.1) 1971/(TC-1-3). Commission Internationale de l'Eclairage, Paris.

4. Cisneros, F., Ellis, M., McKeith, F. K., McCaw, J. and Fernando, R. L. 1996. Influence of slaughter weight on growth and carcass characteristics, commercial cutting and curing yields, and meat quality of barrows and gilts from two genotypes. J. Anim. Sci. 74:925-933.

5. Kim, Y. S., Kim, S. W., Weaver, M. A. and Lee, C. Y. 2005. Increasing the pig market weight: world trends, expected consequences and practical considerations. Asian-Aus. J. Anim. Sci. 18:590-600.

6. Latorre, M. A., Lazaro, R., Valencia, D. G., Medel, P. and Mateos, G. G. 2004. The effects of gender and slaughter weight on the growth performance, carcass traits and meat quality characteristics of heavy pigs. J. Anim. Sci. 82:526-533.

7. Leach, L. M., Ellis, M., Sutton, D. S., McKeith, F. K. and Wilson, E. R. 1996. The growth performance, carcass characteristics, and meat quality of halothane carrier and negative pigs. J. Anim. Sci. 74:934-943.

8. Lee, C. Y., Ha, S. H., Baik, K. H., Sohn, S. H., Park, B.-C. and Park, M. J. 2005. Effects of estradiol implantation on growth, carcass traits and circulating concentrations of insulinlike growth factors (IGFs) and IGF-binding protein-3 in finishing barrows. Livest. Prod. Sci. 96:149-155

9. Lee, C. Y., Lee, H. P., Jeong, J. H., Baik, K. H., Jin, S. K., Lee, J. H. and Sohn, S. H. 2002. Effects of restricted feeding, low-energy diet, and implantation of trenbolone acetate plus estradiol on growth, carcass traits, and circulating concentrations of insulin-like growth factor (IGF)-I and IGF-binding protein-3 in finishing barrows. J. Anim. Sci. 80:84-93.

10. Moon, S. S., Yang, H. S., Park, G. B. and Joo, S. T. 2006. The relationship of physiological maturity and marbling judged according to Korean grading system of meat quality traits of Hanwoo beef females. Meat Sci 74:516-521.

11. NASS. 2008. Hogs: Commercial Slaughter Average Liveweight by Month and Year, US. National Agricultural Statistics Service. http://www.nass.usda.gov/Charts_and_Maps

12. NRC. 1998. Nutrient Requirements of Swine. 10th ed. National Academy Press, Washington, DC.

13. NSIF. 1997. Guidelines for Uniform Swine Improvement Programs. On-farm Programs. National Swine Improvement Federation, Raleigh, NC, USA.

14. SAS. 1996. SAS User's Guide: Statistics. SAS Inst., Inc., Cary, NC, USA.

15. Smith, II, J. W., Tokach, M. D., O'Quinn, P. R., Nelssen, J. L. and Goodband, R. D. 1999. Effects of dietary energy density and lysine:calorie ratio on growth performance and carcass characteristics of growing-finishing pigs. J. Anim. Sci. 77:3007-3015.

16. Wierbicki, E., Kunkle, L. E. and Deatherage, F. E. 1956. Changes in the water-holding capacity and cationic shifts during the heating and freezing and thawing of meat as revealed by a simple centrifugal method for measuring shrinkage. Food Technol. 11:69-73.

17. Yang, H. S., Moon, S. S., Jeong, J. Y., Choi, S. G., Joo, S. T. and Park, G. B. 2006. Effect of sodium bicarbonate injection in pre-rigor porcine $\mathrm{M}$. Longissimus lumborum on pork quality. Asian-Aus. J. Anim. Sci. 19:898-904.

18. 농림부. 2005. “식육의 부위별 - 등급별 및 종류별 구분방법 중 개정고시” 농림부 고시 제 2005-50호.

19. 농림부. 2007. “축산물등급판정세부기준” 농림부고시 제 200740 호.

20. 박만종, 하덕민, 신호원, 이상훈, 김원기, 하승호, 양한술, 정 진연, 주선태, 이철영. 2007. '고체중' 출하돈의 성장효율, 도 체 품질 특성 및 수익성. 한국동물자원과학회지 49:459-470.

21. 이철영, 권오천, 하덕민, 신호원, 이제룡, 하영주, 이진희, 하 승호, 김원기, 김광위, 김두환. 2006. $110 \mathrm{~kg}$ 대비 $130 \mathrm{~kg}$ 에 도 축된 비육돈의 성장효율, 도체품질 특성 및 수익성. 한국동물 자원과학회지 48:493-502.

22. 이철영, 김민호, 하덕민, 박재완, 오관용, 이제룡, 하영주, 박 병철. 2007. 비육후기 사료의 에너지 수준이 '고체중' 출하돈 의 성장효율 및 도체특성에 미치는 영향. 한국동물자원과학 회지 49:471-480.

(접수일자 : 2009. 3. 10. / 수정일자 : 2009. 4. 8. /

채택일자 : 2009. 4. 11.) 